\title{
Preface: Wetlands biodiversity and processes-tools for conservation and management
}

\author{
Pierluigi Viaroli · Marco Bartoli · Jan Vymazal
}

Published online: 4 May 2016

(C) Springer International Publishing Switzerland 2016

An unprecedented interest in wetland science and management has grown in the recent decades, as evidenced by more than 200 books published in the last half-century (Gopal, 2003). A search in the SCOPUS database with "wetland" in the title, keywords or abstract covering the last 55 years (1960-2015) has resulted in 51,865 papers published in scientific journals (about 50\%), book chapters and conference proceedings. From 1960 to 1970, we have found only one paper, but after the "Convention on wetlands of international importance" held in Ramsar in 1971, scientific output has increased exponentially (Fig. 1). A search with the combination of different terms with "wetland" has given an overview of the main research interest and trends in wetland science (Table 1). The citation of "Biodiversity" has become

Guest Editors: Pierluigi Viaroli, Marco Bartoli \& Jan Vymazal / Wetlands Biodiversity and Processes: Tools for Management and Conservation

P. Viaroli $(\bowtie) \cdot$ M. Bartoli

Department of Life Sciences, University of Parma, Parco

Area delle Scienze 11/A, 43124 Parma, Italy

e-mail: pierluigi.viaroli@unipr.it

J. Vymazal

Department of Applied Ecology, Faculty of Environmental Sciences, Czech University of Life Sciences Prague, Kamýcká 129, 16521 Prague 6, Czech Republic frequent after 1992, following the enforcement of the International Convention on Biodiversity. After a few published papers in the 1990s, the term "Ecosystem Services" has increased exponentially since 2000, after the value of ecosystem good and services was recognized as a challenging issue for ecology and economics (Costanza et al., 1997). To some extent, "wetland management" has been associated with "biodiversity," indicating that the latter is considered a key factor of wetland functioning. Paradoxically, most of the wetland ecosystems are dominated by one or few macrophyte species, which indeed provide habitats and chemical conditions suitable for a wide array of vegetal, faunal, and microbial species.

Due to their structures and locations between the terrestrial and aquatic domains, wetlands account for high productivity and, for this reason, they are assumed to provide a variety of ecosystem services as food source, carbon storage, nutrient uptake, flood mitigation, water purification, aquifer recharge, and climate regulation (Mitsch \& Gosselink, 2007). These goods and services have been emphasized as essential benefits for the human wellbeing and of vital importance for developing countries (Millennium Ecosystem Assessment, 2005). Wetlands are also preserved, restored, or constructed for managing biodiversity and wildlife, especially waterfowl (Gopal \& Junk, 2001), and for either controlling pollution from diffuse sources or processing point-source wastewaters (Vymazal, 2001; Kadlec \& Knight, 2002). 


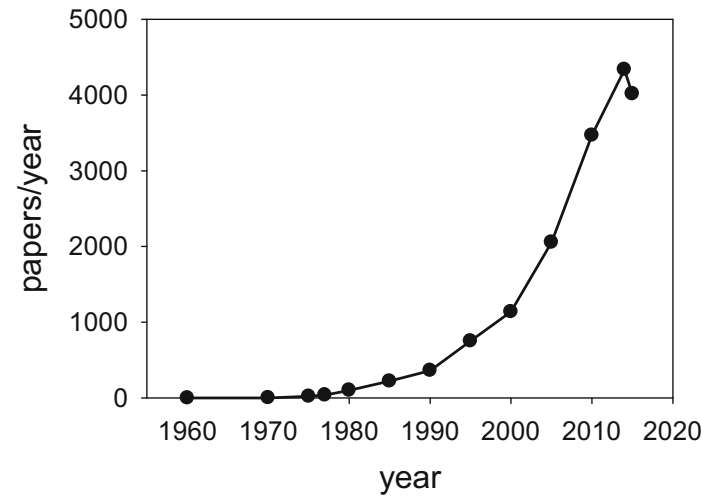

Fig. 1 Number of papers/year published from 1960 to 2015. Search in the SCOPUS database with "wetland" in title, keywords, abstract (last accessed January 21, 2016)

Table 1 Total number of papers published from 1960 to 2015 dealing with wetlands and related issues

\begin{tabular}{lcl}
\hline & No. papers & $\begin{array}{c}>10 \text { Paper/year } \\
\text { since the year }\end{array}$ \\
\hline Wetland & 51,865 & 1975 \\
Wetland and constructed & 7,428 & 1990 \\
Wetland and conservation & 7,318 & 1990 \\
Wetland and restoration & 5,177 & 1990 \\
Wetland and biodiversity & 3,782 & 1995 \\
Wetland and ecosystem and & 1,564 & 2000 \\
$\quad$ services & & \\
Wetland and biodiversity and & 1,480 & 1995 \\
$\quad$ management & & \\
\hline
\end{tabular}

Years from which more than 10 papers/year have been published are also reported. Search in the SCOPUS database (see Fig. 1)

This paradigmatic view of wetland as suppliers of goods and services may also result in other less appreciable effects or disservices, which are naturally induced by fluctuations of environmental conditions. Examples of how contrasting processes shift services toward disservices are given by nitrate removal by denitrification and carbon dioxide sequestration in wetlands. Denitrification, which is beneficial for water quality, at very low redox becomes detrimental for atmosphere due to nitrous oxide emission, which impairs the GHG budget (Elmqvist \& Maltby, 2010). In reed meadows, carbon fixation can result in two contrasting processes: carbon dioxide uptake and sequestration by plants, and methane emission from the anaerobic decomposition of the biomass bulk that accumulates in the wet anoxic soil (Brix et al., 2001).
The balance between $\mathrm{CO}_{2}$ sequestration and $\mathrm{CH}_{4}$ emission is driven by oxygen availability and redox conditions, and is time dependent due to the $\mathrm{CH}_{4}$ persistence in the atmosphere.

In large part of European agricultural floodplains, where river courses are heavily regulated and exploited for irrigation, newly formed wetland ecosystem are becoming more and more rare. Existing wetlands undergo aging, rapid infilling, and surface reduction, which are enhanced by multiple anthropogenic pressures and changing climate (Tockner \& Stanford, 2002). We may expect more extreme fluctuations of water level due to pronounced variations of the aquifer, increasing water requirements for irrigation and altered timing and intensity of precipitations. A large body of literature is now addressing intermittent rivers; we may expect a new wave of research activities addressing intermittent wetlands. Frequent drying and flooding events may determine a cascade of effects on water and sediment quality, mineralization pathways, composition, and succession of micro and macroorganisms community, altering the regulation of wetlands processes and functions (Walters \& Babbar-Sebens, 2016; Watson et al., 2016).

Relict wetlands represent sometimes much less than the empirical threshold of $10 \%$ of a watershed surface and are scattered in the territory, often far and hydrologically disconnected from main water bodies (Racchetti et al., 2011). Under these circumstances, the biodiversity, the processes, and the services generally provided by shallow water bodies shift toward the services provided by more terrestrial ecosystems. This unidirectional path is contrasted by management interventions aiming at the reduction of diffuse pollution, removal of sediments and control of exotic species, connection with main water bodies, or creation of new artificial wetlands (Español et al., 2014).

Apart from the demonstrated feedbacks among shallow ecosystems and human activities, the deep functioning of wetlands, which is the result of multiple interactions among the biota and the physical environments, needs further studies and surely holds new surprises. Ecological paradigms as that of the factors regulating the shift between clear and turbid status in shallow aquatic environments, for example, may be questioned by the abundance and activity of tiny and tolerant chironomid larvae, able to filter large water volumes and control phytoplankton growth more efficiently than the filtering zooplankton (Hölker 
et al., 2015). More than nutrients alone, the interactions among multiple factors (i.e., sediments, external nutrient input, benthic and pelagic primary producers, and benthic macrofauna) may therefore control the shift between turbid and clear states, and vice versa.

Organisms burrowing in the sediment may therefore not only inject oxygen and favor a number of chemically or microbially mediated reoxidation processes turning the sediment redox acceptable for the growth of rooted macrophytes, but may also control planktonic primary production, with another indirect feedback for benthic primary production and associated services (Mermillod-Blondin et al., 2008). Rooted macrophytes, via radial oxygen loss and nutrient uptake, perform similar services, by trapping phosphorous in insoluble forms and favoring the loss of excess nitrogen via nitrification-coupled denitrification (Vila-Costa et al., 2016).

These issues have been debated in the 14th International Wetlands Conference-Wetlands Biodiversity and Services: Tools for Socio-Ecological Development, held in Huesca (Spain), September 14-18, 2014. The conference had 300 registered attendees from 36 countries, 160 oral presentations, and 105 posters covering the issues as listed in Table 1. This special issue is a conference outcome, based on a selection of 16 peer-reviewed papers mainly dealing with biodiversity, water-quality and ecosystem processes and management in a variety of wetland ecosystems.

Two papers address the relevance of river-wetland connectivity as a driver of zooplankton and macroinvertebrate communities (Gozdziejewska et al., 2016; Obolewski et al., 2016). Zooplankton communities which are often neglected in wetland studies, respond to increased eutrophication shifting from crustacean to rotifer dominance (Kuczynska-Kippen \& Joniak, 2016). The evolution of the zooplankton community also relates to the succession from submerged vegetation to helophytes.

Wetlands receive high organic matter inputs, from either the lateral forested areas or from macrophytes stands. Such organic matter bulk fuels decomposition processes which support the wetland food webs (Ágoston-Szabó et al., 2016). In relatively dry areas, the intermittent hydrological regime is the main driver of litter decomposition (Dolinar et al., 2016).

Due to the balance between primary productivity and decomposition processes, wetlands undergo also seasonal fluctuations of oxygen availability and redox potential, with frequent oxic to anoxic transitions (Longhi et al., 2016). In turn, oxygen availability and redox drive the main biogeochemical processes which account for the ecosystem metabolism. In the southern Mediterranean region, water availability is also a key factor in determining the seasonal and interannual evolution of ponds and wetlands, and their biodiversity (Camacho et al., 2016; Fernandez-Zamudio et al., 2016; Florencio et al., 2016). Wetlands' quality and persistence also depend on their catchment, especially on land use at different spatial scales (Novikmec et al., 2016). Atlantic bogs, in their southernmost distribution margin, are threatened by different pressures including water scarcity and land use, and contaminant fallout from distant sources (Cillero et al., 2016).

The interactions between macrophytes and either wet or submerged soils provide functions and services that allow for the removal of nutrients, thus controlling water eutrophication, and can mitigate against xenobiotics (Boz \& Gumiero, 2016; Hernández-Crespo et al., 2016; Pappalardo et al., 2016).

Finally, two contributions address coastal wetlands which are under threat due to sea level rise (Ward et al., 2016). By contrast, well-preserved salt marshes in the Southern Hemisphere are depicted to provide long-term carbon storage and buffering capacity against nutrients and metals (Negrin et al., 2016).

Overall, these studies provide new insight in wetland science emphasizing the occurrence of understudied microinvertebrate communities, the key role played by decomposition processes in relation to intermittent hydrology, and oxygen availability. Most of these ecosystems are under threats from local impacts and from large-scale climate changes. Pressures and losses are especially harsh in the southern margin of wetland distribution.

Acknowledgments We thank Prof. Francisco A. Comin, conference chair, for his support and many colleagues who generously contributed as reviewers.

\section{References}

Ágoston-Szabó, E., K. Schöll, A. Kiss \& M. Dinka, 2016. Mesh size and site effects on leaf litter decomposition in a side arm of the River Danube on the Gemenc floodplain (Danube-Dráva National Park, Hungary). Hydrobiologia. doi:10.1007/s10750-015-2616-3. 
Boz, B. \& B. Gumiero, 2016. Nitrogen removal in an afforested riparian zone: the contribution of denitrification processes. Hydrobiologia. doi:10.1007/s10750-015-2609-2.

Brix, H., B. K. Sorrell \& B. Lorenzen, 2001. Are Phragmitesdominated wetlands a net source or net sink of greenhouse gases? Aquatic Botany 69: 313-324.

Camacho, A., N. Murueta, E. Blasco, A. C. Santamans \& A. Picazo, 2016. Hydrology-driven macrophyte dynamics determines the ecological functioning of a model Mediterranean temporary lake. Hydrobiologia. doi:10. 1007/s10750-015-2590-9.

Cillero, C., R. A. Díaz-Varela, M. Rubinos \& P. Ramil-Rego, 2016. Assessment of anthropogenic pressures on South European Atlantic bogs (NW Spain) based on hydrochemical data. Hydrobiologia. doi:10.1007/s10750-0162778-7.

Costanza, R., R. d'Arge, R. de Groot, S. Farber, M. Grasso, B. Hannon, K. Limburg, S. Naeem, R. V. O’Neill, J. Paruelo, G. R. Raskin, P. Sutton \& M. van der Belt, 1997. The value of the world's ecosystem services and natural capital. Nature 387: 253-260.

Dolinar, N., M. Regvar, D. Abram \& A. Gaberščik, 2016. Water-level fluctuations as a driver of Phragmites australis primary productivity, litter decomposition, and fungal root colonisation in an intermittent wetland. Hydrobiologia. doi:10.1007/s10750-015-2492-x.

Elmqvist, T. \& E. Maltby, 2010. Chapter 2: biodiversity, ecosystems and ecosystem services. In TEEB, the Economics of Ecosystems and Biodiversity. 96 pp [available on internet at http://img.teebweb.org/wp-content/uploads/ 2013/04/D0-Chapter-2-Biodiversity-ecosystems-and-eco system-services.pdf].

Español, C., B. Gallardo, F. A. Comín \& M. R. Pino, 2014. Constructed wetlands increase the taxonomic and functional diversity of a degraded floodplain. Aquatic Sciences 77: $27-44$.

Fernandez-Zamudio, R., P. García-Murillo \& C. Díaz-Paniagua, 2016. Aquatic plant distribution is driven by physical and chemical variables and hydroperiod in a Mediterranean temporary pond network. Hydrobiologia. doi:10.1007/ s10750-016-2701-2.

Florencio, M., C. Díaz-Paniagua \& L. Serrano, 2016. Relationships between hydroperiod length, and seasonal and spatial patterns of beta-diversity of the microcrustacean assemblages in Mediterranean ponds. Hydrobiologia. doi:10.1007/s10750-015-2515-7.

Gopal, B., 2003. Perspectives on wetland science, application and policy. Hydrobiologia 490: 1-10.

Gopal, B. \& W. J. Junk, 2001. Assessment, determinants, function and conservation of biodiversity in wetlands: present status and future needs. In Gopal, B., W. J. Junk \& J. A. Davis. (eds), Biodiversity in wetlands: assessment, function and conservation, Vol. 2. Backhuys Publishers, Leiden, The Netherlands: 277-302.

Goździejewska, A., K. Glińska-Lewczuk, K. Obolewski, M. Grzybowski, R. Kujawa, S. Lew \& M. Grabowska, 2016. Effects of lateral connectivity on zooplankton community structure in floodplain lakes. Hydrobiologia. doi:10.1007/ s10750-016-2724-8.

Hernández-Crespo, C., N. Oliver, J. Bixquert, S. Gargallo \& M. Martín, 2016. Comparison of three plants in a surface flow constructed wetland treating eutrophic water in a Mediterranean climate. Hydrobiologia. doi:10.1007/ s10750-015-2493-9.

Hölker, F., M. J. Vanni, J. J. Kuiper, C. Meile, H. P. Grossart, P. Stief, R. Adrian, A. Lorke, O. Dellwig, A. Brand, M. Hupfer, W. M. Mooij, G. Nützmann \& J. Lewandowski, 2015. Tube-dwelling invertebrates: tiny ecosystem engineers have large effects in lake ecosystems. Ecological Monographs 85: 333-351.

Kadlec, R. H. \& R. L. Knight, 2002. Treatment Wetlands: Theory and Implementation, 2nd ed. CRC Press, Boca Raton.

Kuczyńska-Kippen, N. \& T. Joniak, 2016. Zooplankton diversity and macrophyte biometry in shallow water bodies of various trophic state. Hydrobiologia. doi:10.1007/s10750-015-2595-4.

Longhi, D., M. Bartoli, D. Nizzoli, A. Laini \& P. Viaroli, 2016. Do oxic-anoxic transitions constrain organic matter mineralization in eutrophic freshwater wetlands? Hydrobiologia. doi:10.1007/s10750-016-2722-x.

Mermillod-Blondin, F., D. Lemoine, J.-C. Boisson, E. Malet \& B. Montuelle, 2008. Relative influences of submersed macrophytes and bioturbating fauna on biogeochemical processes and microbial activities in freshwater sediments. Freshwater Biology 53: 1969-1982.

Millennium Ecosystem Assessment, 2005. [Available on internet at http://www.millenniumassessment.org/en/index. html].

Mitsch, W. J. \& J. G. Gosselink, 2007. Wetlands, 4th ed. Wiley, New York: $582 \mathrm{pp}$.

Negrin, V. L., S. E. Botté, P. D. Pratolongo, G. González Trilla \& J. E. Marcovecchio, 2016. Ecological processes and biogeochemical cycling in salt marshes: synthesis of studies in the Bahía Blanca Estuary (Argentina). Hydrobiologia. doi:10.1007/s10750-015-2582-9.

Novikmec, M., L. Hamerlík, D. Kočický, R. Hrivnák, J. Kochjarová, H. Ot'ahel'ová, P. Paĺove-Balang \& M. Svitok, 2016. Ponds and their catchments: size relationships and influence of land use across multiple spatial scales. Hydrobiologia. doi:10.1007/s10750-015-2514-8.

Obolewski, K., K. Glińska-Lewczuk, M. Oźgo \& A. Astel, 2016. Connectivity restoration of floodplain lakes: an assessment based on macroinvertebrate communities. Hydrobiologia. doi:10.1007/s10750-015-2530-8.

Pappalardo, S. E., S. Otto, V. Gasparini, G. Zanin \& M. Borin, 2016. Mitigation of herbicide runoff as an ecosystem service from a constructed surface flow wetland. Hydrobiologia. doi:10.1007/s10750-015-2375-1.

Racchetti, E., M. Bartoli, E. Soana, D. Longhi, R. R. Christian, M. Pinardi \& P. Viaroli, 2011. Influence of hydrological connectivity of riverine wetlands on nitrogen removal via denitrification. Biogeochemistry 103: 335-354.

Tockner, K. \& J. A. Stanford, 2002. Riverine flood plains: present state and future trends. Environmental Conservation 29: 308-330.

Vila-Costa, M., C. Pulido, E. Chappuis, A. Calviño, E. O. Casamayor \& E. Gacia, 2016. Macrophyte landscape modulates lake ecosystem-level nitrogen losses through tightly coupled plant-microbe interactions. Limnology and Oceanography 61: 78-88.

Vymazal, J. (ed.), 2001. Transformation of Nutrients in Natural and Constructed Wetlands. Backhuys Publishers, Leiden: $366 \mathrm{pp}$. 
Walters, K. M. \& M. Babbar-Sebens, 2016. Using climate change scenarios to evaluate future effectiveness of potential wetlands in mitigating high flows in a Midwestern U.S. watershed. Ecological Engineering 89: 80-102.

Ward, R. D., N. G. Burnside, C. B. Joyce, K. Sepp \& P. A. Teasdale, 2016. Improved modelling of the impacts of sea level rise on coastal wetland plant communities. Hydrobiologia. doi:10.1007/s10750-015-2374-2.

Watson, E. B., K. Szura, C. Wigand, K. B. Raposa, K. Blount \& M. Cencer, 2016. Sea level rise, drought and the decline of Spartina patens in New England marshes. Biological Conservation 196: 173-181. 